\title{
SH15 - Análisis de la administración del capital de trabajo a través del ciclo de conversión de efectivo
}

\author{
Leonardo Ramirez Castellón \\ Maestría en Administración Financiera \\ Universidad de San Carlos de Guatemala
}

\section{Resumen}

$\mathrm{E}$ 1 tema de la presente investigación se refiere a la administración del capital de trabajo en las empresas comercializadoras de acumuladores, en vista de que es normal que a esto se le preste poca atención y que falte un adecuado control de los flujos de efectivo. Por lo tanto, se considera que en este sector es necesario la aplicación de herramientas financieras que permitan una adecuada administración del capital de trabajo. El análisis de la administración del capital de trabajo por medio de la utilización de las herramientas financieras y del ciclo de conversión de efectivo, es útil para advertir problemas de liquidez, de rotación de inventarios, recuperación de cuentas por cobrar, incumplimiento en el pago a proveedores, y control de los flujos de efectivo; asimismo, es importante para establecer de forma oportuna el financiamiento necesario para las operaciones de corto plazo. La investigación se realizó con base al del método científico, en su fases indagatoria, demostrativa, y expositiva. La fase indagatoria permitió la recolección ordenada de la información de fuentes primarias y secundarias; la fase demostrativa comprendió el procesamiento y análisis de la información recopilada, y la comprobación de las variables para la prueba de la hipótesis. Finalmente, en la fase expositiva se presentaron los resultados obtenidos en el desarrollo de la investigación. El análisis se realizó en las dos empresas más importantes del sector, tomando en consideración el volumen de ventas, identificándolas como empresa A y empresa B, por razones de confidencialidad.

Palabras clave: Administración del Capital de Trabajo, Análisis Financiero, Capital de Trabajo, Ciclo de Conversión del Efectivo, Ciclo Operativo

\section{Abstract}

$\mathrm{T}$ he subject of this research relates to the management of working capital in trading companies accumulator, given that it is normal that this is little attention and lack adequate control of cash flows. Therefore, it is considered that in this sector the application of financial tools that enable proper management of working capital needed. The analysis of the management of working capital through the use of financial tools and conversion cycle of cash, it is useful to warn liquidity problems, inventory turnover, recovery of receivables, default in payment suppliers, and control of cash flows; It is also important to establish in a timely manner the necessary financing for short-term operations. The research was conducted based on the scientific method in its investigatory phase, demonstration and exhibition. The investigatory phase allowed the orderly collection of information from primary and secondary sources; the demonstration phase involved the processing and analysis of information collected, and checking the variables to test the hypothesis. Finally, in the descriptive phase the results obtained in the development of the research were presented. The analysis was performed on the two most important companies in the sector, taking into account sales volume, identifying them as company A and company B, for reasons of confidentiality.

Keywords: capital management, financial analysis, cash conversion cycle, operating cycle 